\title{
Investigating habitats and affinities of Proterozoic eukaryotes with single- fossil carbon isotope analysis
}

\author{
DR. HEDA AGIĆ ${ }^{1}$, SUSANNAH PORTER ${ }^{1}$, PHOEBE \\ COHEN $^{2}$ AND CHRISTOPHER JUNIUM ${ }^{3}$ \\ ${ }^{1}$ University of California Santa Barbara \\ ${ }^{2}$ Williams College \\ ${ }^{3}$ Syracuse University \\ Presenting Author: hagic@geol.ucsb.edu
}

Early eukaryotes are preserved in the rock record most commonly as organic-walled microfossils (OWM). Single-celled eukaryotic fossils first appeared $\sim 1.65 \mathrm{Ga}$ and diversified into crown-group lineages during the Neoproterozoic, but little is known about their metabolisms, biological affinities, and habitats, whether they were restricted to oxygenated surface waters or lived throughout the water column, including in anoxic ferruginous bottom waters prevalent in Proterozoic oceans. This information is critical to understand if and how different environmental conditions, e.g. stepwise ocean oxygenation during the Neoproterozoic, impacted eukaryotic evolution.

We analyzed C-isotopic composition of individual Proterozoic OWM, from shales of the Paleoproterozoic Changcheng Group, China, and the Tonian Chuar Group, USA, using nano-EA-IRMS with the goal of acquiring insight into their palaeoecology, and the assumption that surface waters would contain heavier $\delta^{13} \mathrm{C}$ values due to export of respired light-C to depth. We analyzed $>200$ microfossils including cell aggregates and filaments that were likely components of benthic microbial mats, and OWM with diagnostic eukaryotic morphology (ornamented and envelope-bearing cells).

In the Chuar Group, OWM show a wide spread of $\delta^{13} \mathrm{C}$ values per sample (-35.8 to $-12.8 \%$, average $-24 \%$ ), presumably incorporating carbon from heterogeneous sources. Depleted values of mat-building prokaryotes (-33 to $-25 \%$ ), are lighter than bulkrock $\delta^{13} \mathrm{C}_{\text {org }}$ from the same samples by $5-16 \%$, consistent with utilization of ${ }^{13} \mathrm{C}$-depleted $\mathrm{C}$-sources from diffusing underlying pore waters, or DIC derived from respired planktonically-produced organic carbon. The most enriched $\delta^{13} \mathrm{C}$ values are observed in envelope-bearing Simia and ornamented Germinosphaera (c. -15\%), heavier than bulk $\delta^{13} \mathrm{C}_{\text {org }}$ by $4-11 \%$. Simia specimens show the broadest $\delta^{13} \mathrm{C}_{\mathrm{OWM}}$ range in shallow oxic samples, but are mostly enriched in deep anoxic samples. Simia is frequently heavier than benthic mat-builders, up to $15.8 \%$. This suggests it preferred oxic waters. In case of an anoxic bottom, it incorporated ${ }^{13} \mathrm{C}$-enriched carbon in the upper column, or utilized an alternative C-metabolism. This is consistent with past interpretations of Simia as a planktonic green alga. Chuaria is ${ }^{13} \mathrm{C}$-depleted relative to bulk $\delta^{13} \mathrm{C}_{\text {org }}$ (average $5 \%$ ), suggesting a benthic habitat, and Leiosphaeridia has the broadest $\delta^{13} \mathrm{C}_{\mathrm{OWM}}$ range confirming its polyphyletic nature. Further single-fossil C-isotope analyses can help reconstruct early eukaryotic ecosystems. 